\title{
Post-fire recovery of a dryland forest remnant in the Wither Hills, Marlborough
}

\author{
Sarah J. Richardson ${ }^{1 *}$, Susan King ${ }^{2}$, Alan B. Rose ${ }^{3}$, Matt S. McGlone ${ }^{1}$ and Robert J. Holdaway ${ }^{1}$ \\ ${ }^{1}$ Landcare Research, PO Box 76040, Lincoln 7640, New Zealand \\ ${ }^{2}$ Peggioh Road, Ward, Marlborough, New Zealand \\ ${ }^{3} 210$ Taylor Pass Road, Blenheim 7201, New Zealand \\ *Author for correspondence (Email: RichardsonS@landcareresearch.co.nz)
}

Published online: 16 April 2018

\begin{abstract}
Fire is a major threat to remnant native woody vegetation in dry, lowland New Zealand. This is because the woody flora lacks specific adaptations to survive fire, and seedling regeneration is constrained by summer drought, limited native seed rain and intense competition from non-native grasses that are often favoured by fire. In December 2000, a fire burnt a 41 ha remnant of mature Kunzea robusta (Myrtaceae) forest in the Wither Hills, Marlborough, a dry region with little remaining native woody vegetation. Shortly after the fire the area was fenced to exclude grazing animals and oversown with pasture species to stabilise the soil. A study was then initiated in June 2001 to determine the rate and direction of native forest recovery using 15 randomly located monitoring plots. Plots were re-measured in summer 2001, 2002, 2003 and 2015. Additional strategically located plots monitored the survival and re-growth of burnt individuals of Kunzea robusta, Sophora prostrata (Fabaceae) and Clematis quadribracteolata (Ranunculaceae). In spite of the dry climate, limited seed rain, oversowing and absence of grazing, woody biomass has started to recover after fire in the Wither Hills but slowly as non-native grasses are overwhelmingly dominant. After 15 years, woody biomass and cover are less than $5 \%$ of the original estimate for the area. However, while fire-damaged Kunzea mostly died, Sophora and Clematis individuals have recovered through resprouting. Our study site is typical of many dryland areas in New Zealand in which native biodiversity is part of a productive landscape and is under threat from fire, weeds and grazing. It is inevitable that a proportion of dryland reserves will be burnt each decade and our results underscore the need for conservation planning to incorporate fire and for experimental investigations to assist with accelerating native vegetation recovery.
\end{abstract}

Keywords: Clematis quadribracteolata; conservation planning; Dactylis glomerata; fire ecology; Kunzea robusta; resprouting; seed limitation; Sophora prostrata; state and transition models

\section{Introduction}

Before human settlement, natural fires were relatively uncommon in New Zealand and were only a significant evolutionary driver in a few, low-statured vegetation types such as wetlands and heathlands (Perry et al. 2014). Consequently, most of the tall forest trees lack specific fire adaptations such as thick bark, serotiny, fire-resistant seed banks, deep roots and lignotubers, and the ability to resprout following fire (Wardle 1991; Ogden et al. 1998; Perry et al. 2014; Richardson et al. 2015). The high frequency and intense fires that followed human settlement burnt all woody vegetation throughout the drier parts of New Zealand resulting in shrub- or grassdominated communities (McGlone 1983). Surviving areas of native secondary and remnant woody vegetation contend with grazing, non-native pastoral and weed species, and are vulnerable to ongoing and repeated fire (Ecroyd et al. 2005; Perry et al. 2010).

Conservation managers need to understand postfire successions in dryland forests to determine whether interventions are necessary to restore or reinvigorate successional processes (Standish et al. 2008). Quantification of the rate and trajectory of recovery following fire in modified landscapes is essential to this task. Post-fire forest successions in dryland production landscapes in New Zealand tend to stall because of two factors: (1) competition from non-native swardforming grasses prevents seedling establishment (Ledgard \& Davis 2004); and (2) limited seed sources, which include both low survival of seeds on burned adults or in soil seed banks
(Rowarth et al. 2007; Perry et al. 2014) and low seed input when remnant populations of native woody species are small and distant. These stall the establishment of woody seedlings, slow biomass accumulation and limit the recovery of pre-fire biomass. In turn, this increases the recovery period to tall forest during which vegetation is more flammable, hence increasing fire frequency and reducing further the chances for forest recovery (Perry et al. 2010, 2015; Tepley et al. 2016).

There are surprisingly few longitudinal studies quantifying post-fire recovery of woody biomass in New Zealand dryland ecosystems and production landscapes. The duration of the lag period between the fire and initial woody establishment, the rate of biomass recovery and the form of that recovery rate curve (Mack et al. 2008), and the amount of pre-fire biomass that recovers are all poorly quantified, particularly in relation to post-fire management of remnants. Globally, fire-adapted ecosystems can have rapid rates of biomass recovery through vigorous resprouting and establishment from fire-resistant seed banks (Whelan 1995). Given the scarcity of such traits in the New Zealand tall forest tree flora (Perry et al. 2014), post-fire biomass recovery rates are likely to be slow. We report on post-fire recovery of a secondary Kunzea robusta forest (a type typical of many dryland conservation covenants) over a 15-year period. Our goals were to determine whether, when and how much woody regeneration had occurred, and quantify resilience of three species (K. robusta, Sophora prostrata and Clematis quadribracteolata) to fire. 


\section{Methods and materials}

\section{Study site}

Sutherland Stream $\left(41.56^{\circ} \mathrm{S}, 173.97^{\circ} \mathrm{E}\right)$ is near Blenheim in the northern Wither Hills, eastern Marlborough, New Zealand. The Wither Hills are formed of weakly indurated conglomerate and claybound gravels overlain by loess (Begg et al. 2000). Elevations range from c. $60-422 \mathrm{~m}$. The topography is steeplyincised and the loess-rich soils subject to tunnel gully erosion and slips (Begg et al. 2000). Mean annual temperature in Blenheim (1981-2010) is $12.6^{\circ} \mathrm{C}$, with a summer (December to February) mean of $17.4^{\circ} \mathrm{C}$ and a winter (June to August) mean of $7.7^{\circ} \mathrm{C}$. Mean annual rainfall in Blenheim (1981-2010) is $711 \mathrm{~mm}$ with a summer mean of $156 \mathrm{~mm}$ and a winter mean of $207 \mathrm{~mm}$ (The National Climate Database, www.cliflo.niwa. co.nz, accessed August 2016).

\section{Fire and management history}

Before humans settled New Zealand, the Wither Hills were likely covered by a forest of drought-tolerant tree species such as Podocarpus totara, Prumnopitys taxifolia, Kunzea robusta and Sophora microphylla. Site-specific charcoal or macrofossil data are lacking but regional charcoal records indicate that Polynesian fires removed these forests and by the time of early European surveys (1840-1860AD) the vegetation was dominated by grasses and shrubs with scattered areas of remnant and secondary forest (McGlone 1983).

In 1994, a 41 ha area was covenanted by the Queen Elizabeth II National Trust and Marlborough District Council to safeguard mature Kunzea robusta (Myrtaceae) forest with subordinate tree species including Coprosma robusta (Rubiaceae), Coriaria arborea (Coriariaceae), Discaria toumatou (Rhamnaceae), Melicytus ramiflorus (Violaceae), Olearia paniculata (Asteraceae) and Pseudopanax arboreus (Araliaceae) (Queen Elizabeth II National Trust 1997). With the exceptions of $O$. paniculata and $D$. toumatou, these subordinate trees were largely confined to gullies and toe slopes, with $K$. robusta dominating the open slopes and ridgelines. A wider matrix of open grassland protected native species such as Sophora prostrata (Fabaceae - a shrub), Clematis quadribracteolata (Ranunculaceae - a liane), Cheilanthes sieberi, C. distans and Pellaea calidirupium (all Pteridaceae) and herbs such as Convolvulus waitaha (Convolvulaceae) and Carex inopinata (Cyperaceae). Pre-fire photographs indicate that the forest understorey was often sparse and non-native pasture grasses common. Pastoral grazing is not practised in the covenant but rabbits, hares and possums are present. The covenant is managed using practices that balance biodiversity conservation, recreation and soil stabilisation and is embedded in a productive landscape, typical of many lowland reserves in New Zealand. Like many such areas it has a long history of weed infestation and species such as Cytisus scoparius (Fabaceae), Berberis glaucocarpa (Berberidiaceae), Euonymus europaeus (Celastraceae), Ulex europeaus (Fabaceae), Salix cinerea (Salicaceae) and Nassella trichotoma (Poaceae) are manually controlled in the reserve.

On 26 December 2000, an accidental fire across the Wither Hills region burnt most of the forest. The fire was more intense in the mature $K$. robusta stands where the fuel loadings were high and few trees survived. In some places the surface litter and soil organic horizon were also incinerated (Fig. 1b). There are no vegetation data to define pre-fire composition and structure, and insufficient unburnt forest to act as a control site. Live tree aboveground biomass in tall K. robusta forest from nearby Peggioh Station $\left(41.9^{\circ} \mathrm{S}, 174.0^{\circ}\right.$ E, c. $35 \mathrm{~km}$ to the south) ranges from c. $30 \mathrm{Mg} \mathrm{ha}^{-1}$ in 40 -year old stands, to c. $130 \mathrm{Mg} \mathrm{ha}^{-1}$ in mature 100 -year old stands (RJH unpubl. data). As prior to the fire the covenant forest was at least $4 \mathrm{~m}$ tall with a continuous canopy in many areas (Fig. 1a), we conservatively estimate that stands were at least 40 years old and therefore the pre-fire biomass at least 30 $\mathrm{Mg} \mathrm{ha}^{-1}$. National biomass estimates for a similar forest and tall shrubland association dominated by Kunzea sp. (Kunzea
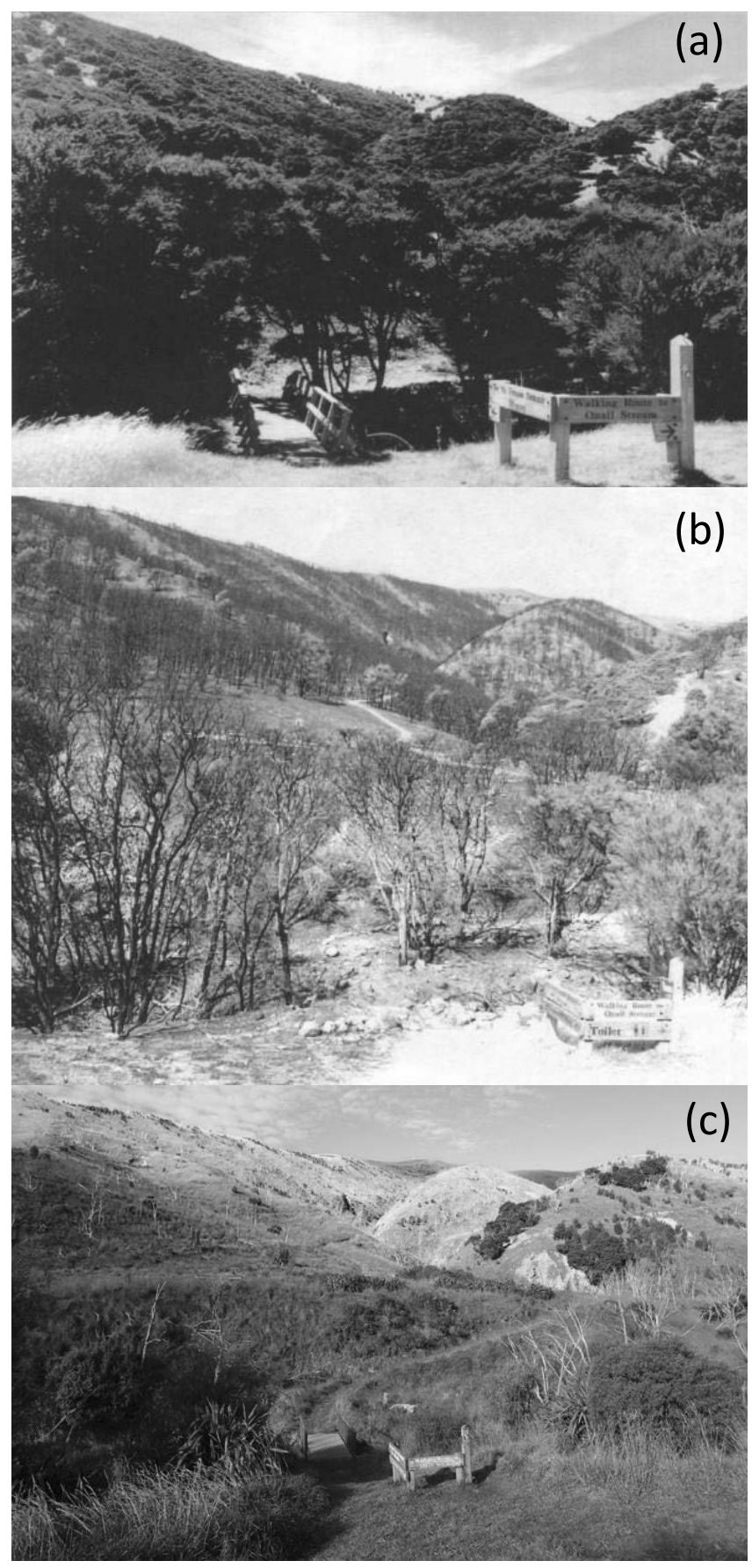

Figure 1. (a) Photo of mature Kunzea robusta forest in the Wither Hills in 1999 before the fire. (b) Photo from January 2001, 11 months after fire showing extensive ash beds beneath dead standing trees. (c) Photo from September 2014 showing limited recovery of woody cover and dominance by non-native grass species. Photographs: Queen Elizabeth II National Trust (Robyn Smith). 
ericoides - Cyathea dealbata - (Leptospermum scoparium)/ Leucopogon fasciculatus - (Coprosma rhamnoides); Wiser et al. 2011) has a mean live tree aboveground biomass of $48 \mathrm{Mg}$ $\mathrm{ha}^{-1}$ ( $6 \pm 1$ SE, $\mathrm{n}=32$ plots) (Holdaway et al. 2017).

Immediately after the fire, the Wither Hills area (including the covenant) was oversown with a mixture of non-native pasture grasses and forbs (Dactylis glomerata (Poaceae), Phalaris aquatica (Poaceae), Lotus corniculatus (Fabaceae), Lotus pedunculatus (Fabaceae), and Cichorium intybus (Asteraceae)) to mitigate the risk of post-fire erosion.

\section{Measuring vegetation recovery}

In June 2001, 6 months after the fire, we established fifteen $10 \mathrm{~m} \times 10 \mathrm{~m}\left(100 \mathrm{~m}^{2}\right)$ plots along three transects to sample the full range of topographic positions (spur crests, faces and gullies) and elevations $(175-350 \mathrm{~m})$ in the covenant. The three transects were selected on a restricted random basis. Transects were evenly-spaced to achieve full elevational coverage of the covenant. Transects were pre-determined on an aerial photograph, and ran north across the topography from origins on the southern boundary of the covenant. The first plot location in each transect was determined by a random number and then plots were located every $100 \mathrm{~m}$ along each transect. We measured the landform index as the arithmetic mean of eight angles to the horizon on the cardinal and intercardinal bearings (McNab 1993). We measured vascular plant composition in June 2001 (6 months after the fire), December 2001 (12 months), December 2002 (24 months), December 2003 (36 months) and December 2015 (180 months) using a modified Braun-Blanquet method (Hurst \& Allen 2007). We visually assessed cover of each species overhanging each plot in classes $(1=<1 \%, 2=1-5 \%, 3=6-25 \%, 4=26-50 \%, 5=51-75 \%, 6$ $=>76 \%)$ and height tiers $(<0.3 \mathrm{~m} ; \geq 0.3-2.0 \mathrm{~m} ;>2.0-5.0 \mathrm{~m})$. We measured the heights of all woody plants $\geq 135 \mathrm{~cm}$ tall on each plot and if they had a diameter of $\geq 2.5 \mathrm{~cm}$ at $135 \mathrm{~cm}$, we tagged them and measured their stem diameter at that height.

In addition to the 15 randomly located plots, we also established three strategically-located plots in June 2001 to follow recovery of burned individuals of three species.

(1) We followed the fate of an isolated stand of Kunzea robusta where foliage was burned but stems survived (plot size of $35 \mathrm{~m} \times 10 \mathrm{~m} ; 350 \mathrm{~m}^{2}$ ). At each measurement we recorded the heights of all stems with live foliage taller than $135 \mathrm{~cm}$ and where stems had a diameter of $\geq 2.5 \mathrm{~cm}$ at $135 \mathrm{~cm}$, we tagged them and measured their stem diameter.

(2) We tagged 40 Sophora prostrata (Fabaceae) which before the fire had been growing in grassland and had all burned to the base. Plot size was $15 \mathrm{~m} \times 50 \mathrm{~m}\left(750 \mathrm{~m}^{2}\right)$. At each measurement we recorded survival and measured the widest orthogonal dimension of living tissue. In 2015, we also measured the perpendicular orthogonal width and height.

(3) We tagged 10 multi-stemmed individuals of Clematis quadribracteolata (Ranunculaceae) in December 2001 that had burned to the base. Plot size was $10 \mathrm{~m} \times 10 \mathrm{~m}\left(100 \mathrm{~m}^{2}\right)$. In December 2002 and 2003 we relocated these individuals and measured the length of the longest shoot and the number of shoots from each cluster. In 2015, we revisited the plot and visually determined whether the species was still present within the plot as individuals could no longer be practicably separated and measured.

\section{Data analyses}

All statistical analyses were completed in R v.3.4.1. (R Core
Development Team 2017). We analysed vegetation composition data by taking the percentage midpoint for each cover class and summing these across height tiers to estimate percentage cover. We categorised species as native woody, non-native woody, native herbaceous or non-native herbaceous following Ngā Tipu Aotearoa (accessed June 2016) and summed cover in each plot in these four groups. We used a linear mixed effects (LME) model to test whether summed cover (transformed as $\log _{10}($ cover +0.5$)$, to homogenise variance) and the rate of change in cover was similar across these four groups across our five measurements. We tested five models predicting $\log _{10}$ cover from log-transformed time since fire (in months) and group (one allowing each group to have a different slope and intercept, one allowing each group to have a different slope but a shared intercept, an additive model between the two terms, a model fitting a different intercept to each group without a slope term for change through time, and a model with a slope for change through time and a single intercept fitted to all groups). We used small sample Akaike's Information Criteria (AICc) to select the most parsimonious model (Anderson 2008). We included plot as a random effect as repeated measures within permanent plots are non-independent. We visually inspected the relationship between fitted values and residuals in the final model to check that residuals were randomly distributed with respect to fitted values. Post-hoc tests for differences in mean cover for each group at each measurement were made using the glht function in the multcomp v.1.4-0 package (Hothorn et al. 2008). Tree dimensions were converted to aboveground biomass following standard allometric methods for the species sampled (Coomes et al. 2002; Holdaway et al. 2014, 2017). We determined the relationships between aboveground biomass and landform index using a general linear model (GLM) with Gaussian error model.

\section{Results}

\section{Vegetation composition}

Vegetation cover increased over the 15-year post-fire period in three of the groups (native woody, native herbaceous and non-native herbaceous), but not in the non-native woody group (Fig. 2). The most parsimonious LME model included a different intercept and slope for each group, reflecting the substantial difference in mean cover between non-native herbaceous species and all other groups and the difference in trend through time across the four groups (interaction term between time and group $F_{3,278}=13.1, \mathrm{P}<0.001$, coefficient of determination $=0.78$, slope between observed and predicted values $=1.01$; Fig. 2 ). Non-native grasses dominated postfire vegetation cover (Fig. 2) and non-native taxa accounted for $58 \%$ of taxa recorded across all measurements, and at least $85 \%$ of total cover in all measurements (Fig. 2). Five non-native grass taxa were found on $\geq 65 \%$ of plots in 2015 (Anthoxanthum odoratum, Dactylis glomerata, Rytidosperma spp., Anthosachne scabra, Phalaris aquatica) of which $D$. glomerata was the most abundant in terms of cover $(97 \%$ where present $\pm 12 \% 1 \mathrm{SE}$ ). The only native grass species found on $\geq 50 \%$ of plots in 2015 was Microlaena stipoides $(2 \% \pm 0.5 \%$ $1 \mathrm{SE}$, where present). Woody cover has recovered slowly and was $<15 \%$ in 2015 (Fig. 2). The most frequent native woody species in 2015 were Kunzea robusta and Muehlenbeckia complexa (both on $27 \%$ of plots). Two non-native woody species (Berberis glaucocarpa and Cytisus scoparius) were found on $\geq 40 \%$ of plots in 2015 . 


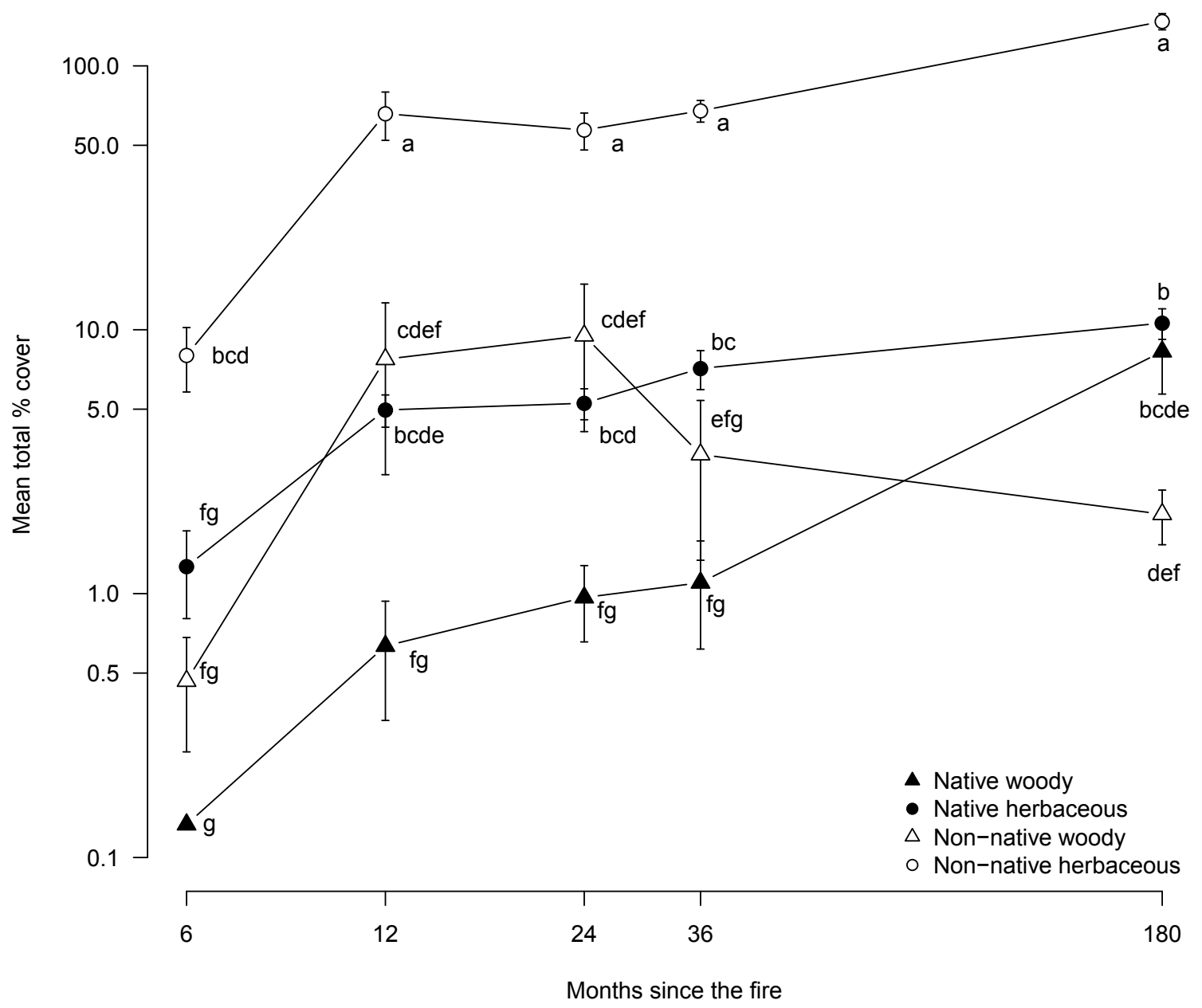

Figure 2. Post-fire vegetation recovery over 15 years in the Wither Hills, Marlborough. Changes in mean foliar cover in four groups (native woody, native herbaceous, non-native woody, non-native herbaceous). Note that cover sums to $>100 \%$ across tiers and both axes use a $\log$-scale. Error bars are \pm 1 SE. Means that share a letter are not significantly different at $\mathrm{P}<0.05$.

\section{Tree regeneration}

No Kunzea robusta or other trees survived the fire in the 15 randomly-located plots. In 2002 and 2003, K. robusta was present as seedlings on six and seven plots, respectively, but no stems were $\geq 1.35 \mathrm{~m}$ tall. In $2015, K$. robusta was present on eight plots ( $53 \%$ of plots) but there were only 25 individuals $\geq 1.35 \mathrm{~m}$ tall $\left(46 \mathrm{ha}^{-1} \pm 241 \mathrm{SE}\right)$, which were confined to just six plots and their mean height was $2.4 \mathrm{~m}( \pm 0.1 \mathrm{~m} \mathrm{SE})$. The only other tree species recorded was a single $1.5 \mathrm{~m}$ tall individual of Coprosma robusta, which we assume to have come from seed. These live individuals equate to a stem density of $167 \mathrm{ha}^{-1}( \pm 851 \mathrm{SE})$, a basal area of $0.03 \mathrm{~m}^{2} \mathrm{ha}^{-1}( \pm 0.03$ 1SE) and aboveground biomass of $0.59 \mathrm{Mg} \mathrm{ha}^{-1}( \pm 0.331 \mathrm{SE})$ (Fig. 3a). Using standing dead tree diameters 6 months after the fire (i.e. not including fallen or incinerated trees), pre-fire basal area was at least $13 \mathrm{~m}^{2} \mathrm{ha}^{-1}$ (range $0.3-24.4 \mathrm{~m}^{2} \mathrm{ha}^{-1}$ ). Recovery of aboveground live tree biomass was not linearly related to landform index $\left(\mathrm{GLM} \chi^{2}{ }_{1}=0.12, \mathrm{P}=0.73\right.$; Fig. $\left.3 \mathrm{~b}\right)$ although plots with aboveground live tree biomass were all on upper slopes (intermediate values of landform index; nonlinear model not fitted because of low sample size).

In the stand of surviving $K$. robusta, 20 stems recovered from burned foliage in the period 0-36 months after the fire, but only three of these stems survived until December 2015.
Regeneration of $K$. robusta has been much greater in this stand than in the randomly-located plots where all adult trees died. In 2015 there were 36 new stems $\geq 1.35 \mathrm{~m}$ tall ( 34 K. robusta, one Coprosma robusta and one Leptospermum scoparium). Including the three stems that survived the fire, these live stems equate to a stem density of $1114 \mathrm{ha}^{-1}$, a basal area of $0.39 \mathrm{~m}^{2}$ $\mathrm{ha}^{-1}$ and aboveground biomass of $1.83 \mathrm{Mg} \mathrm{ha}^{-1}$.

\section{Sophora and Clematis}

Thirty of the 40 S. prostrata tagged in June 2001 survived until December 2015, equivalent to an annual mortality rate of $2.9 \% \mathrm{yr}^{-1}$. Mean width of surviving individuals was $1.2 \mathrm{~m}$ $( \pm 0.091 \mathrm{SE})$ with a width growth rate of $8.6 \mathrm{~cm} \mathrm{yr}^{-1}( \pm 0.69$ 1SE) (Fig. 3c). Mean height of surviving individuals was 1.2 $\mathrm{m}( \pm 0.081 \mathrm{SE})$ with a height growth rate of $8 \mathrm{~cm} \mathrm{yr}^{-1}( \pm 0.5$ $1 \mathrm{SE}$ ). Maximum width and height of surviving individuals in December 2015 were strongly positively related (GLM, $\log ($ height $)=0.04+0.61 \times$ width $\left., \mathrm{r}^{2}=0.62, \mathrm{P}<0.001\right)$. In December 2015, at least one individual bore mature seed pods.

Ten clusters of Clematis quadribracteolata resprouts had appeared 1 year after the fire with a mean shoot length of $71 \mathrm{~cm}( \pm 6.91 \mathrm{SE})$. Eight of these clusters survived until 3 years after the fire by which time mean shoot length was $76 \mathrm{~cm}( \pm 141 \mathrm{SE})$. Mean shoot extension rates in the 3-year 


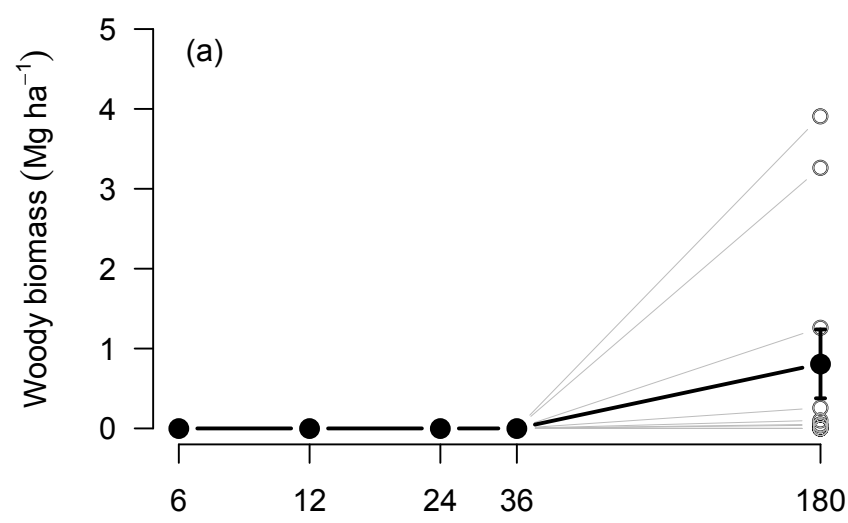

Months after the fire
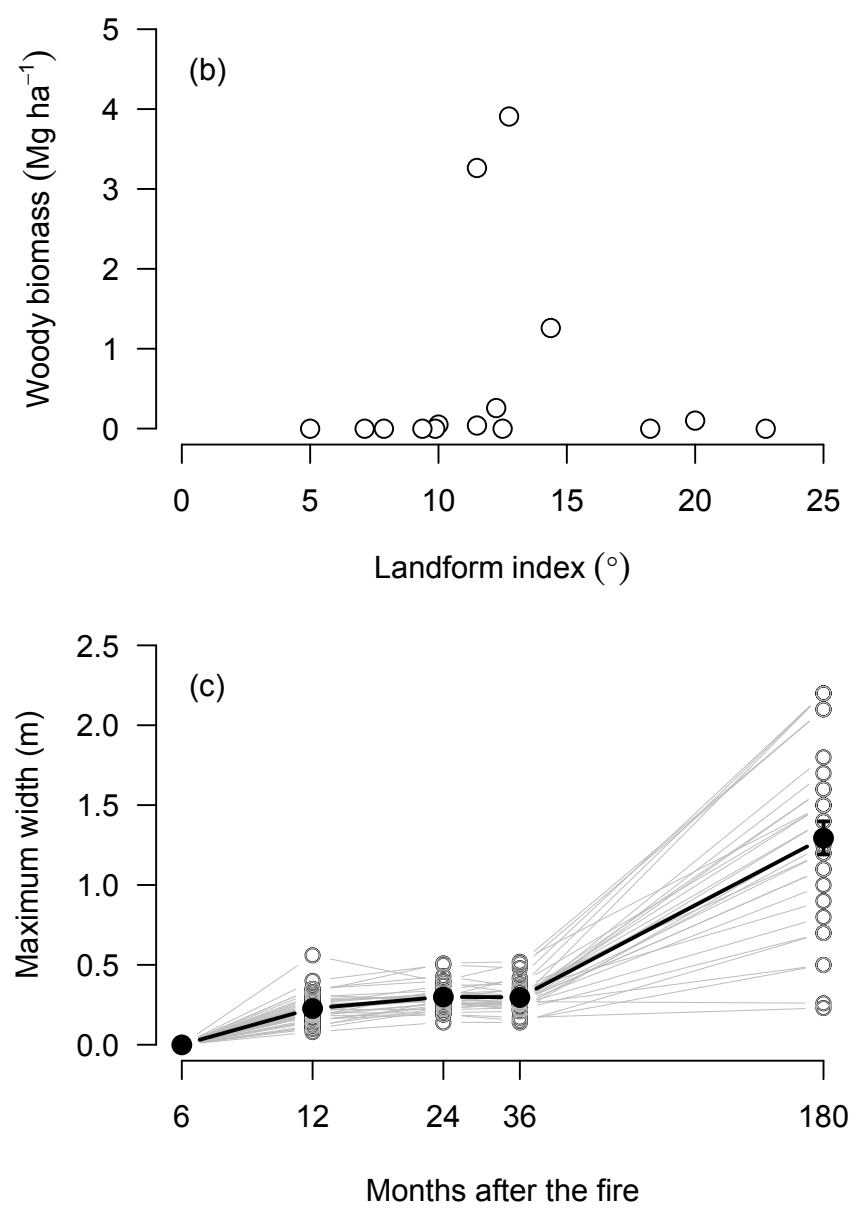

Figure 3. Post-fire vegetation recovery over 15 years in the Wither Hills, Marlborough. (a) Woody biomass. Grey lines are individual plots. Black line is the mean across all plots. Error bars are 1 SE. (b) Woody biomass in 2015 (180 months after the fire) relative to landform index. Each data point is a plot. Low values of landform index are raised topographic positions (e.g. ridges) and high values are depressed positions (e.g. gullies). (c) Recovery of burned Sophora prostrata plants $(\mathrm{n}=40,35,32,32$, 30 , at each measurement). Grey lines are individual shrubs and the black line shows the mean across all shrubs. Error bars are $1 \mathrm{SE}$. period following the fire was $25 \mathrm{~cm} \mathrm{yr}^{-1}$ ( $\pm 51 \mathrm{SE}$ ). Flowering and seeding was observed on one individual in 2002 and by 2015 , the area was densely covered in a tangle of this species and plants were flowering and fruiting prolifically. Individual marked clusters and shoots could no longer be distinguished.

\section{Discussion}

Fire is a significant threat to remnant woody vegetation in dryland production landscapes where competition from non-native grass species and depauperate seed rain constrain opportunities for tree regeneration. In this study, it was at least 3 years before woody biomass began to accumulate and recovery has been slow and spatially restricted. However, this recovery is important because it suggests that oversowing did not stall native woody regeneration entirely. A liane and a small shrub recovered well by resprouting, while regeneration of dominant tree species from seed and tree seedling regeneration was localised around surviving trees and in a few midslope topographic positions. We anticipate that future recovery will be from lateral spread around these foci.

\section{Forest recovery}

The post-fire succession is dominated by non-native grasses, particularly Dactylis glomerata. Sward-forming non-native grasses prevent native species establishment by blocking light (Sessions \& Kelly 2000), smothering seedlings and accumulating a deep litter layer and fibrous root mat that limit seedling root access to the soil (Miller \& Wells 2003). The importance of each factor varies with grass species (e.g. short-statured, root mat-forming Agrostis capillaris vs tall, litter-accumulating Dactylis glomerata), and according to the regeneration niche of the native species (Sessions \& Kelly 2000). In our study, forest was lost from the gullies and D. glomerata accumulated litter depths in excess of $50 \mathrm{~cm}$ in them, sufficient to prevent seedlings accessing the mineral soil, and cast significant shade. Gullies elsewhere often support source populations for reinvasion (Perry et al. 2010) but not in this area. Recovery of the bird-dispersed species recorded in gullies prior to fire (e.g. Coprosma robusta, Pseudopanax arboreus) is likely to be further impeded by the paucity of surviving individuals to act as perching sites (Albornoz et al. 2013). Restoration plantings in gullies are likely to be necessary to restore these species. Litter depths were less on ridges than in gullies but ridge crests are often more drought-prone than other topographic positions, and this might constrain woody seedling establishment (Ashton \& Larson 1996). These limitations may explain why woody biomass only developed on intermediate topographic positions (Fig. 2c).

Dominance by pasture grasses is likely to have occurred in the Wither Hills covenant, regardless of oversowing, but oversowing may have amplified suppression of woody regeneration early in succession. Ledgard and Davis (2004) tested whether the addition of pasture grasses suppressed woody regeneration after fire in native mountain beech (Fuscospora cliffortioides, Nothofagaceae) forest, in the eastern South Island (elevation c. $840 \mathrm{~m}$ ). They found that pasture grasses diminished woody cover (35\% in control plots; $15 \%$ in oversown plots), suggesting grass oversowing delayed, but did not preclude, woody regeneration. Furthermore, seedling densities of trees and shrubs were equivalent after 18 years $\left(5.6\right.$ plants $\mathrm{m}^{-2}$ in controls vs 5.9 plants $\mathrm{m}^{-2}$ in plots seeded with pasture grasses) so in numerical terms of woody seedlings, the outcomes of 
sowing pasture grasses were indistinguishable from not sowing pasture grasses.

At our study site, regeneration of Kunzea was limited where no trees survived the fire but abundant around individuals that survived. We suggest that this reflects one or more of three factors. First, the fire was less intense where trees survived and this reduced fire damage to the soil and seed reserves. Second, surviving trees were a source of new seed as many flowered heavily in the summers following the fire (RJH pers. obs.). Lastly, surviving trees provided summer shade and winter shelter to emerging seedlings, and may have depressed grass sward development. We cannot disentangle these factors in our observational study, and experimental studies are needed to understand the relative importance of fire intensity, seed limitation, microhabitat (shade) and competition from swardforming grasses in determining successional outcomes. Wilson (1994) reported on post-agricultural succession at Hinewai Reserve in Canterbury and noted that while Kunzea was unable to establish into ungrazed non-native grass swards, consistent with our observations, other species such as Muehlenbeckia complexa (a liane) and Pteridium esculentum (a fern) were more competitive in the regeneration phase, and were able to establish into ungrazed pastures of non-native grasses. Based on these observations, we suggest that small-scale adaptive management of grazing or selective herbicides could be a promising tool for expediting Kunzea reestablishment, particularly around regeneration foci such as surviving seed trees.

\section{Fire resilience traits in Sophora and Clematis}

Godley (1979) reported that Sophora prostrata could sucker and we demonstrate that this suckering habit provides fire resilience. Sophora prostrata favours dry open hillsides, terraces and plains (Godley 1979) and while these habitats experienced infrequent fires in the period $7000 \mathrm{BP}$ to $750 \mathrm{BP}$ (Perry et al. 2014), resprouting is unlikely to be a fire-adapted trait in this species because infrequent fire over a period of less than 7000 years would have been insufficient for a fire-specific trait to have evolved. We suggest instead that resprouting is exaptive (i.e. it increases fitness in response to fire, but did not evolve in response to fire; Gould \& Lewontin 1979) and part of the divaricating habit that was advantageous during the lengthy and repeated glacials, because it facilitated persistence on periodically-disturbed alluvial river terraces, and recovery from snow damage and herbivory (Bellingham \& Sparrow 2000; Bond \& Midgley 2001, 2003). We also demonstrate vigorous resprouting in Clematis quadribracteolata. This species is widespread throughout central New Zealand, favouring shrublands and forest margins in which fire-specific adaptations would not be expected. Many lianes are deeprooting to access deep water resources (Wyka et al. 2013) and this extensive belowground investment enables them to survive fire and resprout (Janzen 1975). However, as with S. prostrata, we argue that fire is unlikely to be the primary driver of this resprouting trait in C. quadribracteolata because of insufficient time for a specific adaptation to have evolved. Nonetheless, both species showed resilience to fire through resprouting and recovery of individuals and populations within 15 years.

\section{Recovery of a native dryland forest understorey}

Many short-statured herbaceous forest and shrubland species favour open microsites either beneath a woody canopy or in clearings in woody vegetation and these are particularly vulnerable to extirpation through competition from non- native grasses (Ecroyd \& Brockerhoff 2005). Nevertheless, some short-statured herbaceous species have persisted in microrefugia. Three 'hot rock' fern species were recorded (Cheilanthes sieberi, C. distans, Pellaea calidirupium, all Pteridaceae) and Cheilanthes spp. were always recorded on $25-50 \%$ of plots from 2002 to 2015 . These ferns do not compete directly with non-native grasses but persist on small rocky outcrops and dry ridge crests where grass cover is thinner and shorter. Similarly, the ground-creeping vine Convolvulus waitaha (Convolvulaceae) and small herb Drosera auriculata (Droseraceae) persisted at low abundance.

\section{Conclusion}

Longitudinal studies of succession provide valuable case studies for understanding the rate and direction of vegetation change in relation to disturbance types and specific management actions (Bakker et al. 1996). Woody regeneration in the Wither Hills has been spatially restricted and after 15 years, vegetation is still dominated by non-native grasses that were sown to mitigate erosion risk. Given the management imperative to stabilise hill slopes through oversowing and the potential of non-native grasses to slow successional processes of native species, we suggest that experimental manipulations of low intensity grazing and selective herbicides would be informative to test whether modulating competition from grasses can accelerate woody biomass accumulation.

\section{Acknowledgements}

We thank Chris Morse, Rowan Buxton, Elise Arnst and Laura Young for assistance; Farmer Pete for access; Core Funding to Landcare Research; Robin Dunn from Marlborough District Council for logistical support and permission to sample; and Robyn Smith from the QEII National Trust for providing photographs and historical information.

\section{References}

Albornoz FE, Gaxiola A, Seaman BJ, Pugnaire FI, Armesto JJ 2013. Nucleation-driven regeneration promotes postfire recovery in a Chilean temperate forest. Plant Ecology 214: 765-776.

Anderson DR 2008. Model based inference in the life sciences: a primer on evidence. New York, Springer. 184 p.

Ashton MS, Larson BC 1996. Germination and seedling growth of Quercus (section Erythrobalanus) across openings in a mixed-deciduous forest of southern New England, USA. Forest Ecology and Management 80: 81-94.

Bakker JP, Olff H, Willems JH, Zobel M 1996. Why do we need permanent plots in the study of long-term vegetation dynamics? Journal of Vegetation Science 7: 147-156.

Begg JG, Johnston MR 2000. Geology of the Wellington area. Lower Hutt, New Zealand, Institute of Geological \& Nuclear Sciences Ltd. 64 p.

Bellingham PJ, Sparrow AD 2000. Resprouting as a life history strategy in woody plant communities. Oikos 89: 409-416.

Bond WJ, Midgley JJ 2001. Ecology of sprouting in woody plants: the persistence niche. Trends in Ecology \& Evolution 16: 45-51.

Bond WJ, Midgley JJ 2003. The evolutionary ecology of sprouting in woody plants. International Journal of Plant Sciences 164: S103-S114. 
Coomes DA, Allen RB, Scott NA, Goulding C, Beets P 2002. Designing systems to monitor carbon stocks in forests and shrublands. Forest Ecology and Management 164: 89-108.

Ecroyd CE, Brockerhoff EG 2005. Floristic changes over 30 years in a Canterbury Plains kanuka forest remnant, and comparison with adjacent vegetation types. New Zealand Journal of Ecology 29: 279-290.

Godley EJ 1979. Leonard Cockayne and evolution. New Zealand Journal of Botany 17: 197-215.

Gould SJ, Lewontin RC 1979. The spandrels of San Marco and the Panglossian paradigm: a critique of the adaptationist programme. Proceedings of the Royal Society of London B Biological Sciences 205: 581-598.

Holdaway RJ, McNeill SM, Mason NWH, Carswell FE 2014. Propagating uncertainty in plot-based estimates of forest carbon stock and carbon stock change. Ecosystems 17: 627-640.

Holdaway RJ, Easdale TA, Carswell FE, Richardson SJ, Peltzer DA, Mason NWH, Brandon A, Coomes DA 2017. Nationally representative plot network reveals contrasting drivers of net biomass change in secondary and old-growth forests. Ecosystems 20: 944-959.

Hothorn T, Bretz F, Westfall P 2008. Simultaneous inference in general parametric models. Biometrical Journal 50: 346-363.

Hurst JM, Allen RB 2007. The Recce method for describing New Zealand vegetation: field protocols. Lincoln, Manaaki Whenua - Landcare Research. 39 p.

Janzen DH 1975. Ecology of plants in the tropics. London, Edward Arnold. 72 p.

Ledgard N, Davis M 2004. Restoration of mountain beech (Nothofagus solandri var. cliffortioides) forest after fire. New Zealand Journal of Ecology 28: 125-135.

Mack MC, Treseder KK, Manies KL, Harden JW, Schuur EAG, Vogel JG, Randerson JT, Chapin FS III 2008. Recovery of aboveground plant biomass and productivity after fire in mesic and dry black spruce forests of interior Alaska. Ecosystems 11: 209-225.

McGlone MS 1983. Polynesian deforestation of New Zealand: a preliminary synthesis. Archaeology in Oceania 18: 11-25.

$\mathrm{McNab}$ WH 1993. A topographic index to quantify the effect of mesoscale landform on site productivity. Canadian Journal of Forest Research-Revue Canadienne De Recherche Forestiere 23: 1100-1107.

Miller C, Wells A 2003. Cattle grazing and the regeneration of totara (Podocarpus totara var. waihoensis) on river terraces, south Westland, New Zealand. New Zealand Journal of Ecology 27: 37-44.

Ogden J, Basher L, McGlone M 1998. Fire, forest regeneration and links with early human habitation: evidence from $\mathrm{New}$ Zealand. Annals of Botany 81: 687-696.

Editorial board member: Tim Curran

Received 22 November 2016; accepted 10 January 2018
Perry GLW, Ogden J, Enright NJ, Davy LV 2010. Vegetation patterns and trajectories in disturbed landscapes, Great Barrier Island, northern New Zealand. New Zealand Journal of Ecology 34: 311-323.

Perry GLW, Wilmshurst JM, McGlone MS 2014. Ecology and long-term history of fire in New Zealand. New Zealand Journal of Ecology 38: 157-176.

Perry GLW, Wilmshurst JM, Ogden J, Enright NJ 2015. Exotic mammals and invasive plants alter fire-related thresholds in southern temperate forested landscapes. Ecosystems 18: $1290-1305$.

Queen Elizabeth II National Trust 1997. Sutherland Stream open space covenant (Wither Hills Farm Park) management statement. File 5/8/11.

Richardson SJ, Laughlin DC, Lawes MJ, Holdaway RJ, Wilmshurst JM, Wright M, Curran T, Bellingham PJ, McGlone MS 2015. Functional and environmental determinants of bark thickness in fire-free temperate rain forest communities. American Journal of Botany 102: 1590-1598.

Rowarth JS, Hampton JG, Hill MJ 2007. New Zealand native seed germination requirements: a review. New Zealand Journal of Botany 45: 485-501.

Sessions LA, Kelly D 2000. The effects of browntop (Agrostis capillaris) dominance after fire on native shrub germination and survival. New Zealand Natural Sciences 25: 1-9.

Standish RJ, Sparrow AD, Williams PJ, Hobbs RJ 2008. A state-and-transition model for the recovery of abandoned farmland in New Zealand. In: Hobbs RJ, Suding KN eds. New models for ecosystem dynamics. Washington, DC, Island Press. Pp. 189-205.

R Core Development Team 2017. R: a language and environment for statistical computing. Vienna, Austria, R Foundation for Statistical Computing.

Tepley AJ, Veblen T, Perry GLW, Stewart GH, Naficy C 2016. Positive feedbacks to fire-driven deforestation following human colonization of the South Island of New Zealand. Ecosystems 19: 1325-1344.

Wardle P 1991. Vegetation of New Zealand. Cambridge, Cambridge University Press. 672 p.

Whelan RJ 1995. The ecology of fire. Cambridge, UK, Cambridge University Press. 360 p.

Wilson HD 1994. Regeneration of native forest on Hinewai Reserve, Banks Peninsula. New Zealand Journal of Botany 32: 373-383.

Wiser SK, Hurst JM, Wright EF, Allen RB 2011. New Zealand's forest and shrubland communities: a quantitative classification based on a nationally representative plot network. Applied Vegetation Science 14: 506-523.

Wyka TP, Oleksyn J, Karolewski P, Schnitzer SA 2013. Phenotypic correlates of the lianescent growth form: a review. Annals of Botany 112: 1667-1681. 